\title{
Suppressor of Cytokine Signaling 3
}

National Cancer Institute

\section{Source}

National Cancer Institute. Suppressor of Cytokine Signaling 3. NCI Thesaurus. Code C97975.

Suppressor of cytokine signaling $3(225 \mathrm{aa}, \sim 25 \mathrm{kDa}$ ) is encoded by the human SOCS3 gene. This protein is involved in the down-regulation of cytokine-stimulated signaling. 